\title{
Money Laundering and Penal Offences Related to Them. Mutual Cooperation in the Fight Against Money Laundering
}

Elena Xhina

\author{
Lawyer, Chamber of Advocates, Ebasan, Doctoral School, European University of Tirana
} xhina_elena@yahoo.com

Doi:10.5901/ajis.2015.v4n2p249

\begin{abstract}
For the international community, the fight against money laundering with criminal orgin makes up the major strategic direction of the fight against organized crime. In various theories money laundering is seen as a real danger, as the economy of a state may fall under dependence of criminal organization and illustrations in this sense are not few, among which various countries of Latin America and South East Asia. The phenomenon of money laundering finds specifically suitable space and damages more the states of low economy, states in transition and states with social-political problems and no stability. The danger this type of criminality representes for our country, is big even because of the grave consequences it brings about, hence requireing not only its consideration from the state, but also mutual cooperation with other countries in the fight against this phenomenon. Tracking criminal activity for legalization of monetary means and wealth gained in criminal ways, is both hard and complicated. It requires not only knowledge on the art of tracking, but for the specificness this type of criminality represents, it requires knowledge on the disciplines of economy science and its specific institutes. Involvement in such type of operations, of the experts with economic experience, specifically in the field of circulation of monetary-material means, is as recommendable as much as indispensable, specifically in securing the respective proofs.
\end{abstract}

Keywords: the criminal process, money laundering, the legal framework, cooperation

\section{Albanian Penal Legislation that Criminalizes Money Laundering}

To prevent legalization of the monetary means and other wealths acquired in an illegal way, many countries in the world have provided this activity as a penal offence in their penal legislations. In our legislation, this criminal phenomenon initially was introduced in the law nr.8610, 17 may 2000, "On the prevention of money laundering". This first legal rule was important not only for conceptual side of this criminal activity, until then not known and undefined, but also in the practical sense of it, as institutionalized organized fight against it. It was decided the establishment of a specific structure, such as the one of responsible authority which initially, according to the law, was called Agency of Coordination of Fight against Money Laundering at the Ministry of Finance, with juridical status and the position assigned by the government ${ }^{1}$. Later on, in 2008, it was called the Headquarters of Prevention of Money Laundering, which reports directly to the Minister of Finance and serves as a Financial Intelligence Unit of Albania².

Special importance in this law is given to the integration of our country in the fight the internation community is making. For this purpose, in article 15 it was provided the cooperation with international institutions and organizations for the investigation and taking legal measures, such as those that have to do with confiscation of means and revenues comming from criminal activity, identification and finding the source of criminal properties, issues of extradition, etc. ${ }^{3}$ In 2008 this law underwent considerable improvements with nr. 9917, on 19.5.2008, "On the prevention of Money Laundering and finance of terrorism" 4 . What this phenomenon represents is provided there. "Laundering products of penal offence" has the same meaning as in article 287 of Penal Code" 5 . While as to the product of this penal offence it is provided that: "product of penal offence" has the same meaning as in article 36, comma 1, letter "b", of Penal Code"6.

\footnotetext{
1 Law nr. 8610, date 17 maj 2000, "On the prevention of money laundering "

2 Law nr. 9917, date 19.15.2008, "On the prevention of money laundering and finance of terrorism"

3 Law nr. 9917, date 19.15.2008, "On the prevention of money laundering and finance of terrorism" article 2, comma 9

${ }^{4}$ Same, article 2, comma11.

${ }^{5}$ Same, article 2, comma 13.

${ }^{6}$ Law nr. 9917, date 19.15.2008, " On the prevention of money laundering and finance of terrorism" article 4 
As even mentioned in the beginning of this issue, next to the importance and positive sides, such as prevention of this criminal activity, we have to say that in the law nr. 8610, on 17.05.2000, "On the prevention of money laundering", our penal legislation lacked the formulation of a provision to define this criminal activity as penal offence and provide penal judgment and sentence for respective subjects. This was realized with the constitution of law nr. 9086, on 19.06.2003, where not only the realized deficiencies were fulfilled, but considerable amendments were made to the respective legal framework. With the above law $\mathrm{nr}$. 9086, on 19.6.2003, apart from the provision as penal offence of "laudering the offence products", even these crucial modifications are made in the legislation to the function of this offence, such as:

- Improvement of article 7 of Penal Code in its general part, dealing with the application of penal law for penal offences committed from foreign citizens, by providing the missing additional paragraph after letter ' $g$ ', with this content: "...Laundering of products of penal offence ....", according to the new rule, foreign citizens will be charged based on penal law of the Republic of Albania and for laundering products of penal offence ${ }^{7}$.

- Improvement of article 30 of Penal Code dealing with complementary convictions and concretely of comma 2 reformulating it as follows: "Confiscation of means of committing the penal offence" (second part of this paragraph was not included before).

- This reformulation, as well as the amendment of article 36 of Penal Code, have to do with the confiscation of tools of committing the penal offence and the products of this criminal activity, which on its side regulated the discussable issue in our penal legislation, that of confiscation of material good originating from crime. This fill up was required from the international agreement for this criminal offence, where our country has adhered to ${ }^{8}$.

Initially, in the framework of completion of respective legislation for laundering of dirty money, the completetion of article 287, with that 287/a was made in the Penal Code, titled "laundering of dirty money". In article 8 of law 9086, date19.06.2003, it says: "In article 287 the terminology is modified from "expropriation of property" in "laundering products of penal offence" and its content is specified.

With law no. 9275, on 16.09.2004, this provision was amended with letter 'dh' with the following content: dh."The use and investment in economic or financial activities of the money or means that are products of penal offence ${ }^{9}$. While in 2007 letter "a" is modified and letter "ç" abrogated ${ }^{10}$. With this law article 287/a of Penal Code was also modified and named from "laundering of dirty money" into "opening anonimous accounts", according to which: "... Opening anonimous deposit or current bank accounts or under fake names is sentenced with imprisonment up to three years and a penaly from 200 thousan money up to 2 million money..."11. In the viewpoint of changes, the lawmaker has rightly provided adding a new provision, that of non-declaring of the cash and things of value at the border, which is revealed in the added article 179/a, according to which: "...Non-declaring on entering or exiting the territory of the Republic of Albania, of amounts of any form, bank checque, value metals or precious stones, as well as other value things, over the value permitted by law, makes up penal violation and is sentenced with penaly or two years of imprisonmnet..."12. Therefore, as it is seen, with the corrections made in legislation the vaccum identified in the field of criminalization of money laundering is complemented, which our legal system already treats as penal offence something missing in the past. But, despite the advancement made in comparison to the past, I think that the lawmaker should see the possibility of involving additional provisions in the Penal Code as well as the more complete formulation of the existing legislation, and a wider treatment of the institution of confiscation of material goods originating from crime, about which I think that it is something only generally provided in our penal legislation.

\section{International Legal Acts and Mutual Cooperation in the Fight Against Money Laundering}

\subsection{Convention on laundering, identification, sequestration and confiscation of crime products (1990).}

The convention on laundering, discovery, sequestration and confiscation of crime products, treats those offences bringing profits, such as drug dealing, organized or violent criminality violent money stealing, people abduction.

In this context it would be appropriate to be reminded that this convention, open for signing on 8th November1990

\footnotetext{
7 See law nr. 9086, date 19.06.2003, article1, page1.

8 Same, law nr. 9096, date 19.06.2003, article3 and 4.

${ }^{9}$ Law nr. 9575, date 16.09.2004

10 Law nr. 9686, date 26.02.2007

11 Law nr. 9086, date 19.06,2003.

12 Law nr. 9086, date 19.06.2003, article 6
} 
was preceded by a number of very interesting conventions against drug trafficing even though they were not European conventions. They were all in a world level even though not bringing all the states together. Out of those we mention the Shanghai Convention (1901), that of Hague (1912), of Geneva $(1925,1931,1936)$ and of Bangkok (1931), the Protocol of Lac-succa (1946), of Paris (1948) and of New York (1953). Even more important are: The Unique Convention on Drugs ${ }^{13}$, Protocol of Geneva of 1972 and the Convention of Vienna on psychotrophic substances of $1971^{14}$. Finally we will mention the United Nations Convention signed in Vienna in 1988, which inspired the European Convention as well as the second Protocol of the PIF Convention on the responsibilities of juridical people and money laundering ${ }^{15}$.

The convention aimed at first of all facilitating international cooperation as regards the investigation, freezing and confiscation of properties acquired through any criminal activity and traffics, specifically through drug dealing ${ }^{16}$.

They also aimed at the complementation of already existing instruments in the framework of Eruopean Council. For instance, article 3-1 of European Convention on Mutual Judiciary Assistance treats the issue of order letters in the penal area and underlines that they "target the performance of investigative actions or sending evidence". It comes out of this that the convention does not apply for the discovery and sequestration of assets, which can be confiscated later on. But article 8 of the Convention on assets originating from crime does not exclude mutual assistance as regards investigations on identification of assets acquired illegally. The designers have also had a third intention: to create an instrument which would force the states to provide in their internal legislations efficient measures against grave criminality and regarding the confiscation of assets that criminals have acquired through their illegal activities. The same is valid also for confiscation in value which is not provided in all the national legislations.

It is noticed that the Convention, even though designed within the Council of Europe, does not contain the word "European" in its title, as happens with the other conventions. The reason is that this instrument was supposed to be open for other states, which, even though not European, shared the same goal with the European states. Australia, United States and Canada have taken part in the design of the Convention. ${ }^{17}$

\subsection{Internal measures to assist cooperation}

So as the fight against money laundering is efficient, it is necessary that every state approves a number of measurs in its legislation. We are talking about three of those, that support the idea that harmonization of internal legislations may go side by side with cooperation.

\subsubsection{Incrimination of money laundering}

This incrimination is provided in article 6, which is inspired from the Convention of United Nations of 1988. According to article 6/1, all the states should incriminate some actions that have to do with money laundering, such as convertion or transfer of material goods from people who are aware that these goods are coming from criminal activity and who do it so as to hide the illegal origin, as well as hiding the origin of investment, moving or ownership of objects, for which the author knows are coming from criminal activity. Apart from this, and in conformity with the its constitutional principles, every state incriminates purchasing, keeping or using the material goods when the person purchasing, keeping or using them is aware that they are coming from criminal activities. According to article 6/3 the states are not obliged to aprove incrimination of all the offences provided by article 6/1. Article 6/3 proposes incrimination of those people who are not interested on the origin and are negligent ("author should have doubted that the asset came from crime"), from those who behaved with the intention to make profits or who intend to help a criminal activity. Therefore a big freedom of choice is left to the states. ${ }^{18}$.

\footnotetext{
${ }^{13}$ Which is the most important of all the international conventions. Ratified from 100 states it is mainly made of administrative provisions and decides on all the classified drugs 'the regime of a directed economy', which is applied from the production to consumption, v.Bettati,'Le contole international des stupefiants', Rev.gen.dr.intren.public 1974,f.1.

${ }^{14}$ About all these Conventions, see F.Caballero and Y.Bisiou,Droit de la drogue, Dalloz, $2^{e}$ ed.

15 See infra, $n r .675$ and $v$.

${ }^{16}$ Confiscation is the leading idea of Convention. See introduction, which underlines that grave crimininality should be fought, and for this purpose 'one of the methods is exactly freezing the crime assets'.

17 Explaining report, $n r 18$

${ }^{18}$ France has approved a very wide definition:such as the sale of stolen goods and money laundering make up cheating actions aiming at deceitful justification of products of penal offence, article 324/1 I KP. Law of 13 May1996.
} 


\subsubsection{Investigative Competences}

According to article 4/1, each party takes all the measures, legislative or not, to enable its authorities to "send or freeze the banking, financial or commercial files. None of the parties cannot refer to bank secret to refuse to respect the provisions of this article".

Despite this, according to article 4/2, each party may "approve special investigative techniques so as to make as easy as possible investigation and finding the required object, as well as collection of required evidence". One of those techniques, as provided by law, is the order of observation of bank accounts ${ }^{19}$, spying on the phone calls and the order of presentaion of documentation. This list might be even larger "from the measures that might be taken for instance" it writes in the article. But anyhow, the states are not obliged to approve those measures, but only to consider taking them. Those measures are temporary and permanent, where the most important are the permanent ones, those which have to do with confiscation.

\subsection{Measures for interstate cooperation}

The principles are minaly specified in two articles ${ }^{20}$. The first one is article 7 according to which "the parties decide in between them a most wider cooperation as possible on the investigations and procedures related to confiscation of instruments and products". ${ }^{21}$ The second is artivle 8 , "on their own request, the parties help each other to identify and find the instruments, producst and other objects that might undergo confiscation". We might have noticed that the expression "as wide as possible" is used in the article. This means that the mutual help is not automatic. If the convention provides in details the procedure of cooperation, it also regulates the possibility of refusal of cooperation.

\subsubsection{Procedure of cooperation}

Cooperation might be reached even without request. This is newly introduced in the field of mutual penal cooperation. According to article 10, a state "might communicate to another state, without prior request, various information on instruments and products when it thinks that the communication of such information might help the other state to start or to successfully realize an investigative procedure or a proceeding, as well as when it thinks those informations may become the incentive for it to present a request ...". It is understood that the information should not be communicated in case they will impede investigation in the territory of the state sending it ${ }^{22}$. But in the most common practice, cooperation is realized through request from the requesting state for the receiving state which should respond.

\subsubsection{Refusal of cooperation}

Cooperation does not take place in all the cases. Article18 describes in details the reasons for refusal. This article provides two aspects: on one side the requested state may pretend any time that there exists a reason for refusal and the requesting can do nothing but accept it; it is clear that the requested state can not pretend other reasons for refusal except those provided in this article. Naturally the requested state is never obliged to give reasons for refusal even

\footnotetext{
${ }_{19}$ Observation is an investigative technique consisting of secretly following the movements of certain people, without arresting or interrogating them

${ }^{20}$ Except for an original instrument that should be mentioned is the agreement related to the illegal traffic through the sea, article 17 of the United Conventions apply to, against illegal trafficing of drugs and psycotrophic substances. It is signed in Strasburg on 31 January 1995 and has come to power on 1 May 2000. This article enables the state, which doubts that a ship with the flag of another state does drug traffic, to ask that state the authorization to stop the and check the ship.

${ }^{21}$ From where comes the consequence provided by article 7, according to which each party will regulate its internal right in such a way that it properly responds to the obligation of cooperation: for instance, if a state acknowledges only the system of confiscation in value, it will have to change its legislation in such a way as to execute the request from another state, which applies the system of confiscation of the object itself. See explaining report $n r .35$

22 Explaining report, nr. 38.

${ }^{23}$ Important notion, which we find applicable in the European Convention on Transfer of Proceedings, article 11/j.
} 
though it can do it. Article 18 provides many reasons of refusal. The cases of refusal used in all types of cooperation such cases listed in article 18/1 are:

- "The requested measure is contrary to the basic principles of the requested state". Every state has to first of all take care of respecting those principles. During the preparatory works, the Committee of experts has given several examples: the procedure for which the request has been made for, falls against the European Convention of Human Rights, namely the articles 5 and 6 ; there exist serious reasons to believe that the life of person would be put in danger; the requesting state presents a very exagerated request ...23;

- "Execution of request may threaten the sovranity, security, public order or fundamental interests of the requested state"24. Those "fundamental interests" are the interestes of the state and not those of individuals. This formula is quite unclear and might imply even certain economic interests;

- "The requested state evaluates whether the importance of the case talked about in the request justifies taken the required measures". Several cases are implied with this expression: there exists a certain disproportion between the requested measure and the offence it is related to (the principle of proportionality); the request has to do with very small amounts; the request has to do with very light offences as regards its nature;

- "The offence the request is made for, is an offence of political or fiscal character". Experts have come to the conclussion that no offence related to drug trafficing can be considered as such;

- "The state requested considers that the measure requested would go against the principle ne bis in idem". Therefore this principle is equally valid both in the national right and the international one;

- "The offence the request is made for, would not be considered as penal offence from the legislation of the requested state, if it would be committed in the territory under its jurisdiction". This clause refers to the rule of double incrimination ${ }^{25}$. But it says in the article that this motif of refusal is applied in the investigative part only if the mutual help in the field requires implementation of constraining measures.

Cases of refusal for certain types of cooperation - provided by article $18 / 2$ and on.

Refusal may have to do first with several types of constraining and temporary measures. According to article 18/2, mutual help with investigative intentions, when is presupposes constraining measures, and mutual help with the intention of taking temporary measures, may be refused from the requested party in cases when such actions, taking into consideration the legislation of this country, would not be committed if we would be talking about internal analogue cases. According to article $18 / 3$, when the legislation of the requested state provides it, cooperation for investigative purposes (when the latter implies constraining measures) and cooperation for taking temporary measures, may be refused when the requested measures are not realizable according to the legislation of the requesting state, or as regards the authorities of the latter, when the request is not authorized both from a judge or a magistrate of prosecution office.

Apart from these cases, article 18/7 specified that a state cannot be protected behind behind the bank secret to refuse any type of cooperation ${ }^{26}$. The maximum that it can do is to request the authorization of a judge or prosecutor to remove the bank secret, if it is provided in its legislation.

\subsubsection{Partial Refusal}

The Convention speaks very shortly about this refusal. On one side, the requested state may postpone the execution of measures provided by the request in case they risk to damage investigations or proceedings performed by its authorities (article 19) ${ }^{27}$. On the other side, before refusing cooperation, the requested state examines together with the requesting state if necessary, whether the request may be partially executed oron certain conditions that it might consider as necessary (article 20). These conditions for instance, may have to do with the rights of thirds.

\footnotetext{
${ }^{23}$ Explaining report nr.60.

${ }^{24}$ See in the framework of article $2 b$ of the European Convention of Mutual Judiciary Help in the penal area.

${ }^{25}$ Whic is usually interpreted in the international right: it is not necessary that nomen jurist to be identical, as the requested state will make an evaluation in concreto, see the explaining report nr.65.

${ }^{26}$ Convention of United Nations against illegal trafficing of drugs (Vienna, 1998) provides that the bank secret can never be used to refuse cooperation as regards the profits coming from penal offences related to drugs and money laundering.

${ }^{27}$ This decision to postpone the execution is usually taken in coordinaation with the requesting state 


\section{Recommendations}

The fight against organized crime does not end with the incrimination of the criminal organizations. Many European Countries, including our country, have been amending their penal and procedural laws, by consenting with the concept belum justum: by coercing sentencing measures, extending the competences of the police authorities and using special investigation techniques.

1. Some of the fundamental aspects, which should be the focus of the specialized state organs in their fighting against organized crime, are the discovery and suppression of the criminal groups as well as the individualization and concretization of their property;

2. Issuance and application of more flexible normative acts allowing the sequestration and the confiscation of property of illegal origin would be of a great interest.

3. A useful policy would be the one allowing and promoting the effectuation of the nominative payment instruments suchlike cheques and payment orders. If nominative transactions were attained properly, it would be simpler for the fiscal verification of the money spent.

4. International cooperation to limit the so-called "fiscal paradises" in countries allowing illegal money transit via secret accounts in their local banks. Fiscal paradises are used by criminal organizations in order to be able to disguise their trails, so limiting investigation effectiveness. There have been proposals recently to apply trade sanctions to countries that promote and admit fiscal paradise. The issue is that, in order to be efficient, such sanctions should be supported by many countries and in the general frame of a wide international collaboration.

5. Increasing the effectiveness, correctness and the preventive nature of legislation and sanctions, which continue to be somewhat limited, as far as they are not entirely specific and sufficient?

6. Creating an evaluation system to analyze the effectiveness of the legislation.

7. Further approaching the necessary provisions of the law for the confiscation and sequestration of the revenues from criminal activities with the Western partners, especially regarding their concretization for the executive organs.

\section{References}

Association of Microfinance Institutions of Kosovo - Training on the Prevention of Money Laundering, Prishtina 2011.

Brahimllari, G.,2010. Novelties and problematics of the new antimafia law, Publishing House "Erik".

Convention of Palermo with law nr.8920, on 11.07.2002;

Convention of United Nations signed in Vienna in 1988,"On the reponsibility of juridical persons and money laundering";

Convention on laundering, discovery, sequestration and confiscation of products of crime (1990);

Convention on laundering, discovery, sequestration and confiscation of income coming from crime, on 27.01.2006;

Convention on money laundering, discovery, sequestration and confiscation of assets acquired through crime and on the Financing of Terrorism (2005);

Elezi,I.,2010. Penal Right (Particular Part), Publishing House "Erik" ,Tirana.

European Convention of Mutual Judiciary Help in the penal area;

Gashi, R., 2013. Organized Crime. Publishing house Eric.

Gjonca,L. \& Gjonca,G.,2005. Criminology, ILAR 2005.

Gjonca,L.,2005. Corruption, ILAR 2005.

Halili, R., 2011. Criminalogy. Publishing house Pristina.

Hysi, V., 2005. Criminology. Publishing house Tirana.

Hysi,V., Latifi,V. \& Elezi, I., 2012. The policy of fighting criminality. Publishing house Pristina.

Johnson, S., 2011. Corruption and public finances. Publishing house Dudaj.

Krasniqi,K.,2009.Some characteristics of organized crime in Kosovo and other Balkan states, Vienna 2009.

Law nr. 7895 on 27.01.1995 "Penal Code";

Law nr. 7905 on 21.03.1995 "Code of Penal Procedure of the Republic of Albania";

Law nr. 8610 on 17.05.2000 "On the prevention of money laundering" amended with law nr. 9804 on 19.06.2003, designed in conformity with the standards of European Union according to the directive 91/308/EC of 10.06.1991 "On the prevention of use of financial system for money laundering" and the directive 01/97/EC of 04.12.2001 which amends the directive 91/308/EC;

Law nr. 8610, on 17. 05. 2000, amended with law nr. 9917, on 19.15.2008; "On the prevention of money laundering"

Law nr. 8610, on 17.05.2000, "On the prevention of money laundering";

Law nr. 9086, on 19.06.2003 "On laundering of products of penal offence";

Law nr. 9575, on 16.09.2004 "The use and investment in economic or financial activities of the money or objects that are products of 
penal offence";

Law nr. 9686, on 26.02.2007 "On the change of law nr.9575, on 16.09.2004";

Law nr. 9917, on 19.15.2008, "On the prevention of money laundering and financing of terrorism";

Law nr.9275, on 16.09.2004, "On the ratification of the UN declaration on the fight against corruption and bribery";

Muçi, SH., 2012. Penal Right (General Part). Publishing House Dudaj.

National Strategy of the Republic of Kosovo on the prevention and fight against informal economy, money laundering, finance of terrorism and financial crime 2014-2018, Pristina 2014

Nuredini, V.,20011. The challenge of prevention money laundering. Publishing house Albjuris.

Poda, Z., 2010. Organized crime. University publishing house Tirana.

Pradel,J.,Corstens,G. \& Vermeulen,G.,2009. European Penal Right, Papirus 2009.

Project of the Ministry of Interiors - Intersectoral fight against organized crime, traffics and terrorism, Tirana 2007.

Project Report of CARPO on the situation of organized crime, Strasburg 2006.

Regional Project CARPO, Report on the situation of organized crime and economic crime in South East Europe, Strasburg 2006.

Report of the European Council on the situation of organized crime and economic crime in South East Europe, Strasburg, August 2006.

Report of the National Council of Security of USA - Threats of international organized crime, Uashington.

Selmani, A., 2007. Manual for prosecutors and judges, Albjuris, Tiranë.

Summary of international Acts,2010. Publication of the Center of Public Editions.

Shegani,A.,2007. E Drejta Penale e Krahasuar, Albjuris, Tiranë.

Shehu.L.,2013. Lecture on organized crime and its characteristics, Tirane, 2013.

Unit for Financial Intelligence- Typology of money laundering and Finance of Terrorism in the Republic of Kosovo 
